\title{
Effects of Leadership Styles and Job Satisfaction on Organizational Commitment in Myanmar Government Organizations
}

\author{
EI CHO ZIN LATT \\ Global MBA, International School of Management, \\ University of Thai Chamber of Commerce (UTCC), Bangkok, Thailand \\ mayaugust3@gmail.com
}

DOI: 10.31364/SCIRJ/v7.i10.2019.P1019705

http://dx.doi.org/10.31364/SCIRJ/v7.i10.2019.P1019705

\begin{abstract}
The purpose of this study is to examine 1) the effect of leadership styles on job satisfaction and organizational commitment and 2) the effect of job satisfaction on organizational commitment in Myanmar Government Organizations. In this study, data were collected from 380 Myanmar government employees who were currently working under mid-level manager/ officers by questionnaires survey. Relevant statistical techniques including anova, t-test and correlation were used to analyze the data. The results showed that leadership styles positively and significantly correlate with job satisfaction and organizational commitment. And, job satisfaction also positively effect on overall organizational commitment. But, job satisfaction negatively related with continuance commitment in this study. The main contribution of this study is to support a small evidence of public employee information in Myanmar labour market and to upgrade current knowledge of leadership, job satisfaction and organizational commitment in Myanmar government employees. The findings of this study will be able to motivate both Myanmar Government Organizations and all government employees.
\end{abstract}

Index Terms: Job Satisfaction, Leadership Style, Myanmar Government Organizations, Organizational Commitment

\section{INTRODUCTION}

Human resource is an important role of strategic management in order to operate an organization well. Whether it is called "people," "labor," "intellectual capital," "human capital," "human resources," "talent," or some other term, they are critical to create strategic success and competitive advantage. The productivity, profits and success of an organization depend on the employees and the leadership style of the leader. And, employees' performance and their commitment also depend on how much they satisfy their job. Spector (1997) states that job satisfaction influences people's attitude towards their jobs and various aspects of their jobs. In the other hand, leadership styles of an organization play an important role to become successful organizations and the wellbeing of the society. Leaders can identify employees' personal skills and hidden qualities which can benefit the society. Leadership is an interaction between two or more members of a group that often involves a structuring or restructuring of the situation and the perceptions and expectations of members (Bass, 1990, p.19).Burns (1978) articulate the concept that a leader can be a transformational or transactional in politics. And, Bass (1985) extended theories if transformational and transactional leadership.
In $21^{\text {st }}$ century, the success of an organization depends on both physical assets of the organization and the leadership, job satisfaction organizational commitment and working performance of the employees. If the employees do not satisfy their job, they will leave from the work quickly. The more satisfied their job, the more they commit towards organizations. Organizational commitment as an attitude reflects feelings such as attachment, identification and loyalty to the organization as an object of commitment (Morrow, 1993). Allen and Meyer (1990) and (1991) found that organizational commitment was composed of three dimensions: affective commitment, normative commitment and continuance commitment. According to Mowday et al., (1982), high level committed employees may have a strong belief in the organization's objective and values, desire to continue being members in the organization. The purpose of this study is to examine the effects of leadership styles and job satisfaction on organizational commitment because leadership of the leader and employees' job satisfaction can create a happy workplace and working environment that can support the success of an organization. And a good leadership style and satisfaction can extend employees' commitments to their organizations. Although there are some studies for private sector employees in Myanmar labour market, there is no strong study and evidence for government employees. So there is a scarcity of information for the Myanmar government employees and their development is delaying in the current situation.

\section{THEORETICAL FRAMEWORK AND HYPOTHESIS}

\section{A. Leadership Styles}

The success of an organizational depends on the leaders of the organization and their leadership styles. Leader can affect employees' job satisfaction, job performance, creativity, organizational commitment and behavior in an organization. A leader has to be a role model of his/ her subordinates in the place of honesty, patience, enthusiastic and problem solving (Northouse, 2015). Leadership is the way to produce a clear vision, give the self-confidence to their subordinates, created the detail through coordination and communication (Bohn \& Grafton, 2002). All the terms of the position, personality, responsibility, influence process; instrument to achieve a goal, behaviors are included in the word "leadership" (Limsila \& 
Ogunlana, 2007). Lussier \& Archua (2007) and McLaurin (2008) also gave an explanation of leadership that was the process by which the leader's influence on their employees to achieve organizational goals. According to "The Philosophy of Leadership" by Hodgkinson (1983), depending on the work style of the leaders can be divided into (1) dictatorial leadership, (2) authoritarian leadership (autocratic), (3) democratic leadership (participative) and (4) the laissez-faire type (delegative). According to Yukl (2005), there are numerous studies on the theory of leadership and it can be summarized into five broad theories: (1) trait (2) behavioral (3) contingency or situational approach and (4) contemporary integrative approach and (5) power and influence approach. Burns (1978) was the first person to articulate the concept that a leader can be considered either transformational or transactional in his treatment of political leadership. After Burns, Bass (1985) extended the theories of transformational and transactional leadership. Miller \& Topping (1989) hypothesized transformational and transactional leadership styles to exert direct active and passive affected on the employees and organization respectively.

In 1991, Bruce Avolio and Bernard Bass introduced a concept that distinguished three different leadership styles, namely transactional, transformational, and laissez-faire leadership styles. In 1993, Hollday \& Combs who describe leadership in the frame of communication competence suggested two more leadership styles: relational (affective) and task (content).In the current situation of the world, transformational leaders are often seen as ideal agents of the followers in uncertain times and high risk-taking for the complex organizations and dynamic business environment. In contrast, transactional leaders gain legitimacy through the use of rewards, praises and promises that would satisfy followers' immediate needs (Northouse, 2010).

\section{B. Transformational and Transactional Leadership}

Transformational leadership is a source of inspiration and vision for subordinates and bringing change in an organization (Burns, 1978); Weber, 2009). Transformational leaders are trusted, adored by their employees and the employees have loyalty and respect to their leaders. In the past studies of Avolio and Bass (1991), Fairholm (1991), Lowe, Kroeck and Sivasubra- hmaniam (1996), Stevens, D'Intino and Victor (1995), transformational leadership is more innovative, productive, effective, and satisfy. Bass (2004) depicted transformational leadership with four distinct factors: (1) charisma or idealized influence (2) inspirational motivation (3) intellectual stimulation and (4) individualized consideration. Bass and Avolio (1994) identified that idealized influence leader give employees' needs more than their own and they never use their authority for their personal interest. According to Bryman et al., 1996, idealized influence is the charismatic actions of the leader that means self-interest of the leaders can advantage and develop mission and purpose of the organization. By reviewing the idea of Bass \& Avolio (2004), inspirational motivation can produce enthusiastic excitement; achieve ambitious goals, and increase expectations and communicating confidence of the employees or followers. Intellectual stimulation is the creativity and innovation role of leaders and their followers are stimulated with questioning assumptions and approaching old situations in new ways (Bass \& Riggio, 2006; Nicholason, 2007). In order to solve the problems, the leaders always encourage their followers for trying new approaches and methods. Bass \& Riggio (2006) and Nicholason, (2007) identified that individualized consideration is paying special attention to the needs of individual follower in order to achieve the growth of employees. Before them, Avolio (1999) implied that a transformational leader performs as the role of a mentor who is focusing on employees' success and development to their highest level in individualized consideration.

Transactional leadership is a negotiation process between the leader and employees. Transactional leadership is a part of a style of leadership that focuses on supervision, organization and performance. The transactional leadership style is firstly described by Max Weber in 1947 and Burns (1978) developed the model of transactional leadership then extended by Bernard Bass in 1985.By Bass model of leadership (1990), transactional leadership has three dimensions (1) contingent rewards: rewards for good performance and clarifying work (2) management by exception (active): leaders actively monitoring the work of followers and management by exception (passive): leader intervene only when problem arise and (3) laissez-faire or non-leadership behavior: contrast to the active leadership styles of transformational and transactional leadership. As noted by Howell and Avolio (1993), the difference between management by exception (active) and management by exception (passive) is in the timing of the leader's intervention. Transactional leaders focus on motivating employees through the punishment and reward mechanism.

Bass (1985) originally conceptualized Full Range of Leadership Model (FRLM) with three leadership styles: transformational leadership, transactional leadership and laissez-faire. It is composed of nine-factors of dimensions: five factors (idealized influence behavior, idealized influence attribution, inspirational motivation, intellectual stimulation, individualized consideration) for transformational leadership, three factors (contingent reward, active management by exception and passive management by exception) for transactional leadership and one laissez-faire leadership (Bass et al., 2003). And, transactional leadership is based on material/economic exchange and transformational leadership is based on social exchange. Bass (1998, pp7) believes that every leader will display each of the above mentioned styles to some extent.

\section{Job Satisfaction}

Job satisfaction plays an important role and is frequently studied in the field of organization behavior. Job satisfaction is described as a pleasant or positive emotional condition derived from an occupation of an employee (Locke, 1976). While Mitchel \& Larsel Hoppock (1935) defined it as "a combination of psychological, physiological and environmental circumstances that causes a person to say: I' m satisfied with my job". Based on Spector (1997), job satisfaction is defined as "the extent to which people like (satisfaction) or dislike (dissatisfaction) their jobs" and it can influence the attitudes of people towards their job. According to Herzberg (1957), if the employees are more satisfied on their organizations, they will add more value and effort to their organizations. Smith (1992) stated that job satisfaction can reduce the cost with less absence, task errors and turnover. According to George and Jones (2008), job satisfaction is "the collection of feelings and 
beliefs that people have about their current jobs. Nelson and Quick (2009) defined it as "a pleasurable or positive emotional state resulting from the appraisal of one's job or job experiences". Zimmerman et al. (2009) also found the effect of job satisfaction on turnover intention. It means the poor performer of the employees is they are less satisfied with the job, and it is more likely to quit them from the work.

After analyzing the literatures of Hamermesh (1977) and Freeman (1978), job satisfaction is impacted with employees' personal and job characteristics. Sloane, Battu, and Seaman (1995) stated that "highly educated employees are more likely to suffer from educational mismatch" and Clark (1997) is also agreed that the higher level of education of employees, the lower their satisfaction. After reviewing the previous studies, there are many factors that effects on job satisfaction of the employees like financial rewards, supervision of the managers, co-worker, workload and stress level, opportunities and working conditions. In 1997, Spector proposed that there are nine different aspects of a job that effect on a worker's overall evaluation of the job. They are payment, promotion, benefits, co-worker, supervision, communication, rewards, operating procedures and nature of work. Comm and Mathaisel (2000) also found that "job satisfaction is influenced by the level of pay and performance, employee benefits, training, recruiting, learning curve inefficiencies, reduction in the client base, job design, life satisfaction, autonomy, growth satisfaction, satisfaction with co-workers, satisfaction with supervisors and customer satisfaction".

Hackman and Oldman (1976) explained aspects of job satisfaction with Job Characteristic Model. Hackman and Oldham's (1980) original formulation of job characteristics theory argued that the outcomes of job redesign were influenced by several moderators. This theory identified 5 core job characteristics, which lead to three psychological states, which in turn lead to 4 outcomes. These job characteristics are skill variety, task identity, task significance, autonomy and feedback. According to this theory, employees are more satisfied the jobs that provide these core characteristics than the jobs that do not have these characteristics. These core characteristics lead to three critical psychological states: (a) experienced meaningfulness of the work (b) responsibility for outcomes and knowledge of results. And so, these three critical psychological states can lead to outcomes such as job satisfaction, work motivation, quality of performance and work effectiveness.

\section{Organizational Commitment}

Organization commitment is critical to create motivated business environment and job satisfaction in workplace because organization commitment is linking individual to organizations. Sheldon (1971) defined organizational commitment is the positive evaluation of an organization and the intention to work towards the organization's goals. Organizational commitment is viewed as a psychological connection that individuals have with their organization, characterized by strong identification with the organization and a desire to contribute to the accomplishment of organizational goals (Meyer\&Allen 1997). According to Lumley (2010), the concept of organizational commitment has attracted considerable interest in an attempt to understand and clarify the intensity and stability of an employee's dedication to the organization. Gbadamosi
(2003) contends that the more favorable an individual's attitudes toward the organization, the greater the individual's acceptance of the goals of the organization, as well as their willingness to exert more effort on behalf of the organization. Organizational commitment was connected to very significant work-related factors: employee turnover, performance and absenteeism (Mowday et al., 1979; Romzek, 1990; Ward et al., 1995; Walton, 1985). Organizational Commitment measured willingness to work, the fitness of the firm and workers, and employee's loyalty.

Meyer and Allen (1991) identified the organizational commitment with three components: (1) affective commitment: individual's emotional connection of the employees to organization, (2) continuance commitment: acknowledgement of the consequences of leaving the organization and (3) normative commitment: an ethical responsibility to stay with the organizations. Each component of commitment had different behavioral outcomes, though an individual may reflect varying degrees of all three components of commitment to a particular focus (Meyer \& Allen, 1997).

Based on the literature reviews and objectives of this study, the hypotheses are developed as follows:

H1: There is a significance relationship between leadership styles of the mid-level officials/ managers and employees' job satisfaction.

H1 (a): Transformational leadership has positively effect on employees' job satisfaction.

H1 (b): Transactional leadership has positively effect on employees' job satisfaction.

H2: There is a significance relationship between leadership style of the mid-level officials/ managers and organizational commitment of the employees.

H2 (a): Transformational leadership has positively effect on organizational commitment of the employees.

H2 (b): Transactional leadership has positively effect on organizational commitment of the employees.

H3: There is a significance relationship between job satisfaction and organizational commitment of employees.

H3 (a): Employees' job satisfaction positively effects on affective commitment.

H3 (b): Employees' job satisfaction positively effects on normative commitment.

H3 (c): Employees' job satisfaction positively effects on continuance commitment.

\section{RESEARCH METHODOLOGY}

The survey of present study approaches the 380 employees who are currently working under mid-level manager of officers in Myanmar Government organizations to collect data for testing all research hypotheses. All dependents and independents variables are measured with 5 point Likert scale. Leadership styles are measured with Multifactor Leadership Questionnaire (MLQ) by Bass and Avolio (2004), job satisfaction is with Job Satisfaction Survey (JSS) by Spector (1994 \& 1997) and organizational commitment is with Organizational Commitment Survey (OCS) by Mayer \& Allen (1997). Data are analyzed with correlation and appropriate statistical methods. The reliability of the survey is tested with Cronbach's alpha $(\alpha)$. According to George and Mallery (2003), the value of Cronbach's Alpha $(\alpha)$ is $>0.9$ as excellent, $>0.8$ as good, $>0.7$ as acceptable, $>0.6$ as 
questionable, $>0.5$ as poor and $<0.5$ as unacceptable. Based on the pretest, the questions are reliable.

\section{ANALYSIS AND RESULTS}

This study is to understand the relations of leadership styles on job satisfaction and organizational commitment and the relation of job satisfaction on organizational commitment in Myanmar Government organizations. The demographic factors of the employees cannot effect on employees' job satisfaction and organizational commitment ( $p>0.05$ ). According to the mean scores results, the employees from Myanmar Government organizations satisfy transformational leadership of their leaders and moderately satisfy overall leadership styles, transactional leadership, their job satisfaction and commitment to their organizations. The table shows the values of means, standard deviation and the relationships of the variables. Based on the data results, leadership styles $(r=.488)$, transformational leadership $(\mathrm{r}=.603)$ and transactional leadership $(r=.268)$ significantly and positively correlate with job satisfaction at $\mathrm{p}<0.01$. These findings indicate that leadership styles effects on job satisfaction. And, leadership styles

$(\mathrm{r}=.215)$, transformational leadership $(\mathrm{r}=.251)$ and transactional leadership $(r=.268)$ have also significantly and positively correlation with organizational commitment in this study at $\mathrm{p}<0.01$. This shows that employees are willing to commit to their organization when the leadership styles of their leaders are strong. Job satisfaction also positively and significantly correlates with organizational commitment $(\mathrm{r}=.385)$, affective commitment $(\mathrm{r}=.525)$ and normative commitment $(\mathrm{r}=.437)$ at significance level of $\mathrm{p}<0.01$. But, it negatively correlates with continuance commitment $(r=-.158$, $\mathrm{p}<0.01$ ). These findings indicate that employees give affective and normative commitment to their organizations when they satisfy their jobs. In the other hand, although employees satisfied their jobs, employees can leave their organizations because they do not have the fear of loss of work. They can stand for the risk related to leaving their organizations. As a consequence, the employees are not aware the cost of leaving from their organizations (continuance commitment). Since the respondents of this study are government employees in Myanmar Government organizations, some people especially for the older persons may satisfy the lives of government employees. In the other hand, the benefits like payments and facilities of government employees in Myanmar are still small in comparison with the other ASEAN countries as Myanmar is a developing country. The Government of Myanmar is trying to fulfill some needs of their employees in the current situation. But, they have to put effort more than the benefits they get during transformation time of the government. And, they may sometimes have the pressure of the cost of living standard. That's why; some government employees especially for the middle age may think to leave their organizations although they satisfy their jobs.

\section{DISCUSSIONS AND CONCLUSION}

This study aims to examine the effects of leadership styles on job satisfaction and organizational commitment and the effect of job satisfaction on organizational commitment in Myanmar Government organizations. The result of this study finds that leadership styles and its two dimensions: transformational and transactional leadership have significance relationships with employees' job satisfaction like the previous studies of Hakan Erkutlu (2008) in hospitality industry in Turkey, M.L. Voon, M.C. Lo, K.S. Ngui and N.B Ayob (2011) in public sector organizations in Malaysia and Meng Zhou (2012) in Bangkok. This finding highlights that employees satisfy their jobs when they moderately satisfy the leadership styles of their leaders and they satisfy intangible rewards of transformational leadership such as personal growth, professional value, motivation and self-esteem. The more employees satisfy leadership of their leaders, the more employees' job satisfaction will create. And leadership styles and its two dimensions also effect on organizational commitment in this study. These are the same results with the studies of Chiun-Lo, Ramayah and Min (2009) and Mahmood (2015) in Pakistan companies. This finding implies that the role of leadership style is really important in creating happy, good and effective workplace and strong organizational commitment of the employees. Besides, this study result that there is a significance relationship between job satisfaction and organizational commitment of employees as same as Meng Zhou (2012) in Bangkok working people, Kelly (2015) in South African National Defense Force and Manish Suri (2015) in Bangkok private banking sector. This finding highlights that employees commit to their organizations when they satisfy their job in Myanmar government organizations. Job satisfaction binds an individual to their organizations. These findings highlight that the role of leadership and employees' job satisfaction are critical roles to create strong organizational commitment of the employees.

Therefore, the implications of this research are to advance leadership knowledge of all employees, to empower employees' job satisfactions and to aware organizational commitments of the employees in order to get full performance of employees in the implementation of the development of the country. And the results and findings of this research can become a small evidence of public employee information in Myanmar labour market.

Future research can be extended to the whole Myanmar Government sector by identifying the leader and including all employees because of the two limitations of this research. These are the survey of this study was personally distributed to the government employees who are currently working in Nay Pyi Taw and the leaders of the respondents were not the same person. They are from different organizations, culture and nature of work. Therefore, the results were not enough to generalize to other locations and to conclude the whole government sector. However, the above results and findings will be able to benefit not only to the Myanmar Government organizations and also government employees as the findings can understand government employees' attitudes towards their leaders (mid-level officers especially Deputy Directors) and their organizations in Myanmar. The findings of this research will motivate both the government and the employees. 


\begin{tabular}{|c|c|c|c|c|c|c|c|c|c|c|}
\hline Variables & Mean & S.D & LS & TFL & TSL & JS & OC & AC & NC & $\mathrm{CC}$ \\
\hline Leadership Styles (LS) & 3.2182 & 0.3581 & 1 & & & & & & & \\
\hline Transformational Leadership (TFL) & 3.4362 & 0.6434 & $.741^{* *}$ & 1 & & & & & & \\
\hline Transactional Leadership (TSL) & 2.9224 & 0.3727 & $.550^{* *}$ & $.480^{* *}$ & 1 & & & & & \\
\hline Job Satisfaction (JS) & 3.2044 & 0.4890 & $.488^{* *}$ & $.603^{* *}$ & $.268^{* *}$ & 1 & & & & \\
\hline Organizational Commitment (OC) & 2.9865 & 0.3070 & $.215^{* *}$ & $.251^{* *}$ & $.268^{* *}$ & $.385^{* *}$ & 1 & & & \\
\hline Affective Commitment (AC) & 3.2729 & 0.4792 & $.381^{* *}$ & $.447^{* *}$ & $.252^{* *}$ & $.525^{* *}$ & $.573^{* *}$ & 1 & & \\
\hline Normative Commitment (NC) & 3.0429 & 0.4691 & $.271^{* *}$ & $.290^{* *}$ & $.176^{* *}$ & $.437^{* *}$ & $.636^{* * *}$ & $.406^{* *}$ & 1 & \\
\hline Continuance Commitment (CC) & 2.6434 & 0.6516 & $-.171^{* *}$ & $-.183^{* *}$ & .065 & $-.158^{* *}$ & $.532^{* * *}$ & $-.220^{* *}$ & $-.120^{*}$ & 1 \\
\hline
\end{tabular}

\section{References:}

Bass BM (1985). Leadership and performance beyond expectations. Free Press: New York.

Bass, B. (1990), Bass and Stogdill's Handbook of Leadership, Free Press, New York, NY.

Bass, B. M., \& Avolio, B. J. (1991), The multi-factor leadership questionnaire, Palo, Alto, CA: Consulting Psychologists Press

Bass, B. M., \& Avolio, B. J. (1994). Improving Organizational Effectiveness:Through Transformational Leadership. Thousand Oaks: Sage Publications Inc

Bass, B. M., \& Avolio, B. J. (2004). Multifactor Leadership Questionnaire: Manual and Sampler Set. ( $3^{\text {rd }}$ ed). Menlo Park. Mind Garden, Inc

Bass, B., \& Riggio, R.E. 2006. Transformational Leadership ( $2^{\text {nd }}$ ed.). Mahwah, NJ: Lawrence Erlbaum

Burns, J. M. (1978). Leadership. New York: Harper and Row Publishers.

Chiun-Lo. M, T. Ramayah and Min. W.H (2009). Leadership styles and organizational commitment: a test on Malaysia manufacturing industry. African Journal of Marketing Management. 1(6), 133-139.

Comm CL, Mathaisel DFX (2000). Assessing employee satisfaction in service firms: An Example in Higher Education. The Journal of Business and Economic Studies, 6 (1), 43-53

Erkutlu,H., (2008). "The impact of transformational leadership on organizational and leadership effectiveness: The Turkish case". Journal of Management Development, 27(7), 708-726

Gbadamosi, G. 2003. 'HRM and the commitment rhetoric: Challenges for Africa', Management Decision, 41 (3), $274-280$

George, J.M., \& Jones, G.R. (2008). Understanding and Managing Organizational Behavior. $\left(5^{\text {th }}\right.$ ed). Upper Saddle River: New Jersey, Pearson Prentice Hall.

George, D. and Mallery, P. (2003) SPSS for Windows step by step: A simple guide and reference. 11.0 update $\left(4^{\text {th }}\right.$ ed). Boston: Allyn \& Bacon

Hackman, J.R. \& Oldham, G.R. 1975. Development of the job diagnostic survey. Journal of Applied Psychology $60,159-170$
Hamermesh D.S. (1977). Economic aspects of job satisfaction, Labour Market Analysis, John Wiley, New York, 53-72.

Herzberg, F.,Mausner, B., Peterson, R.D. and Capwell, D.F (1957). Job attitudes: Review of research and opinions. Pittsburgh: Psychological Service of Pittsburgh. Retrieved from https://doi.org/10.1177/ $\underline{001316445901900219}$

Howell, J. M., \& Avolio, B. J. (1993). Transformational leadership, transactional leadership, locus ofcontrol, and support for innovation: Key predictors of consolidated business-unit performance. Journal of Applied Psychology, 78, 891-902

Kelly,J. (2015). The Relationship between Organizational Commitment and Job Satisfaction of Commissioned Officers within an Arm of the South African National Deffence Force. (Master of Administration in Industrial Psychology). Retrieved from https:// pdfs.semanticscholar.org/pdf

Locke, E. (1976). The nature and causes of job satisfaction. In: M. Dunnette (Ed.), Handbook of industrial and organizational psychology. Chicago: Rand McNally. Retrieved from https://core.ac.uk/ download/pdf/4269371.pdf

Lumley, E. (2010). Exploring the relationship between career anchors, job satisfaction and organizational commitment. (Unpublished Master's Dissertation)Department of Industrial and Organizational Psychology, University of South Africa, Pretoria.

Mahmood, A., (2015), Effects of Leadership Styles on Organizational Commitment in Public and Private Sectors of Pakistan. (Master Thesis) Retrieved from https://pdfs.semanticscholar.org/ad29/89b03f26717645 bf252f4c447c7e8cc7bb2b.pdf

Meyer, J.P. \& Allen, N.J. (1991). A three-component conceptualization of organizational commitment. Human Resource Management Review, 1, 61-98

Meyer, J. \& Allen, N. 1997. Commitment in the Work place: Theory, Research and Application

Mowday, R. T., Steers, R. M., \& Porter, L. W. (1979). The measurement of organizational commitment.Journal of Vocational Behavior, 14, 224-247. London: Sage.

Nelson, D, L. \& Quick, J.C. (2009). Organizational Behavior "ORGB”. Mason: Ohio, South-Western 
Cengage Learning. Retrieved from http://ijbhtnet. com/journals/Vol_3_No_5_May_2013/6.pdf

Nicholson II, W. D. 2007. Leading where it counts: An investigation of the leadership styles and behaviours that define college and university presidents as successful fundraisers. International Journal of educational advancement, 7 (4), 256-270.

Northouse, P. G. (2015). Leadership: Theory and practice. Sage publications

Romzek, B. S. (1990). Employee investment and commitment: the ties that bind. Public Administration review, 50, 374-381

Sheldon,M.(1971).Investments and involvements as mechanisms producing commitment to the organization. Administrative Science Quarterly. 16,143150

Spector P. 1997. Job Satisfaction, Sage Publications, Thousand Oaks, CA.

Suri. M (2014). The study of relationship between Job Satisfaction, Organizational Commitment \& Demographic factors: A Case Study of Private Banking Sector in Bangkok. (Master Thesis)

Voon M.L, Lo M.C., Ngui K.S \& Ayob N.B. (2011) The Influence of Leadership Styles on Employees' Job Satisfaction in Public Sector Organizations in Malaysia. International Journal of Business, Management and Social Sciences, 2 (1), 24-32

Walton, R. E. (1985). From control to commitment in the workplace. Harvard Business Review, 63, 15-30

Weber, M. (2009). The Theory of Social and Economic Organization. New York: Simon and Schuster.

Yukl GA (2005). Leadership in organizations (6 ${ }^{\text {th }}$ ed.). Upper Saddle River, NJ: Prentice-Hall

Zoug.M (2012). The Factors Effect of Transformational and Transactional Leadership and Organizational Commitment on the employees' Job Satisfaction. (MBA). Retrieved from https://scholar.utcc.ac.th/ handle / 6626976254/428 
